\title{
PERBANDINGAN EFISIENSI LATERAL FREE DAN FIXED HEAD ELEMEN HINGGA PADA TANAH KOHESIF DAN NON-KOHESIF
}

\author{
Arya $^{1}$, Inda Sumarli ${ }^{2}$, dan Ali Iskandar ${ }^{3}$ \\ ${ }^{1}$ Program Studi Sarjana Teknik Sipil, Universitas Tarumanagara, Jl. Letjen S. Parman No.1 Jakarta \\ arya.325160037@stu.untar.ac.id \\ ${ }^{2}$ Program Studi Sarjana Teknik Sipil, Universitas Tarumanagara, Jl. Letjen S. Parman No.1 Jakarta \\ indasumarli@gmail.com \\ ${ }^{3}$ Program Studi Sarjana Teknik Sipil, Universitas Tarumanagara, Jl. Letjen S. Parman No.1 Jakarta \\ aliiskandar@ft.untar.ac.id
}

Masuk: 11-01-2021, revisi: 14-01-2021, diterima untuk diterbitkan: 11-02-2021

\begin{abstract}
Foundation is the important way for designing upper structure or below structure. Designing foundation is a must, especially for the complicated structure. There are so many things to be focused on sturdy foundation. One of those design steps is designing foundation with lateral loading. Lateral loadings are so many different variances of it, depends on the location of installation. Then, we can identify the efficiency of individual pile on group pile cause of lateral loadings. The efficiency of pile can be analyzed by Finite Element method, which is the foundation is located on the real condition of loading and soils between the pile. And then, Finite Element is supposed to identify the foundation with free-headed pile or fixed-headed pile on cohesive or cohesionless soils.
\end{abstract}

Keywords: Free-Head; Fixed Head; Cyclic Loading; Finite Element Method; Eficiency.

\begin{abstract}
ABSTRAK
Fondasi merupakan hal penting bagi struktur atas maupun struktur bawah. Perencanaan fondasi sendiri sangat dibutuhkan, apalagi untuk membuat struktur yang rumit, diperlukan fondasi yang kuat. Banyak sekali hal-hal yang harus diperhatikan untuk bisa merancang fondasi yang kokoh. Salah satunya dengan perancangan pembebanan akibat beban lateral. Beban lateral sendiri dapat bermacam-macam bentuknya, bergantung pada pondasi tersebut dipasang di daerah yang seperti apa. Efisiensi lateral tiang yang umum digunakan, didapatkan dari eksperimen di lapangan, dimana kondisi kepala tiang adalah pada kondisi free-head. Hal ini bertujuan juga untuk melihat kinerja fondasi tersebut apabila dalam kondisi free-head, maupun fixed-head dengan tanah kohesif dan non-kohesif.
\end{abstract}

Kata kunci: Kepala Tiang Bebas; Kepala Tiang Jepit; Beban Lateral Siklik; Metode Elemen Hingga; Efisiensi

\section{PENDAHULUAN}

Sebelum masuk kedalam topik ini, alangkah lebih baik jika mengetahui pengertian bored-pile sendiri. Bored Pile sendiri merupakan pondasi tiang yang pemasangannya dilakukan dengan cara mengebor tanah terlebih dahulu, yang kemudian diisi tulangan yang telah dirangkai lalu dicor beton (Hardiyatmo, 1996). Mengenai jenis pondasi yang ada, masing-masing mempunyai cara pemasangan dan karakteristik yang berbeda-beda. Lingkungan sendiri memiliki peranan penting dalam pemilihan tipe pondasi yang akan dipasang. Pondasi sendiri memiliki pemodelan perletakan (free head / fixed head) yang berbeda-beda tergantung kebutuhan owner dan konsultan dalam mendesain suatu beban bangunan (gaya lateral dan aksial).

Menurut Reese, et al (2011)., untuk daya dukung lateral sendiri bergantung pada jarak spasi tiang kelompok dan terdapat faktor reduksi tiang kelompok. Semakin tinggi deformasi yang timbul akibat beban, maka akan semakin berbahaya bagi struktur atas. Karena kegagalan pondasi akan sangat fatal, dan safety factor dari bangunan tersebut akan semakin menurun.

Selain itu, pengaruh jenis tanah juga penting untuk kita ketahui. Karena tanah sendiri mempunyai sifat fisik yang dapat mempengaruhi tegangan pada pondasi tersebut. Secara umum, tanah sendiri dibagi menjadi 2, yaitu kohesif dan non-kohesif. Pengaruh jenis tanah sendiri dapat membawa pengaruh terhadap deformasi dan efisiensi dari 
pondasi tersebut. Bahkan terdapat jenis tanah yang memberikan gaya Negative Skin Friction terhadap pondasi yang dipasang, yaitu gaya aksial yang searah terhadap beban luar.

Selain membahas mengenai pondasi, artikel ini juga akan menjelaskan sedikit mengenai tanah. Menurut (1984), tanah sendiri didefinisikan sebagai agregat mineral dan bahan-bahan organik yang terdapat partikel cair dan juga gas yang mengisi suatu ruang pada sebuah bidang. Pada penelitian ini, akan ditinjau lebih lanjut mengenai efisiensi lateral yang dihasilkan oleh pondasi dengan dua kondisi kepala tiang yang diuji pada kesempatan ini (Free Head / Fixed Head) terhadap tanah kohesif dan non-kohesif sebagai variabel terikat yang dipakai. Dan juga dapat melihat karakteristik sebuah pondasi akibat pembebanan yang akan diuji. Sebagai alat bantu, saya akan menggunakan aplikasi elemen hingga dan program bantu berbasis pada data Kawanda (2015) pada penyelidikan tanah di kawasan Legok, Tangerang sebagai acuan data numerik, dan juga menggunakan data yang sudah diteliti (Inclinometer dan Load Cell) sebagai acuan data sebenarnya.

Mengenai metode yang dipakai dalam perhitungan ini, saya menggunakan metode elemen hingga. Menurut C.S Desai, et al. (2001), setiap elemen dapat didiskretisasi menjadi beberapa elemen kecil dan sederhana untuk mempermudah perhitungan. Susunan elemen tersebut dimulai dari one-dimensional body lalu menjadi twodimensional body dan yang paling kompleks adalah three-dimensional body.

Berdasarkan identifikasi masalah yang telah disusun sebelumnya, maka didapat beberapa rumusan masalah yang akan didapat adalah sebagai berikut:

- Melihat karakteristik dan gaya dalam tiang, dan lainnya akibat pembebanan yang dilakukan dengan menggunakan program metode elemen hingga pada pondasi kelompok $3 \times 2$.

- Melihat efisiensi yang dihasilkan oleh kelompok tiang / pondasi dengan korelasi data yang valid.

- Melihat perbandingan antara masing-masing kondisi kepala tiang antara free-headed pile dan juga fixedheaded pile pada tanah kohesif dan non-kohesif.

- Serta, untuk melihat daya dukung pondasi akibat pembebanan lateral dengan metode statik unloadingreloading.

\section{METODE PENELITIAN}

Pada konsep perhitungan ini, akan diberikan 2 kondisi tanah yang berbeda yaitu tanah kohesif dan non-kohesif. Pada masing-masing jenis tanah tersebut, diberikan data-data parameter yang digunakan sebagai acuan untuk perhitungan secara numerik. Kelompok pile akan dibebankan secara siklik dengan konfigurasi beban dimulai dari $0 \mathrm{kN}$ sampai $240 \mathrm{kN}$. Untuk kelompok pile sendiri, dipakai parameter tiang, digunakan jenis bored-pile non-linear yang akan dijelaskan pada Tabel 1 .

Tabel 1. Tabel spesifikasi tiang tunggal dan kelompok

\begin{tabular}{ccc}
\hline Spesifikasi Pile: & Tiang Tunggal & Tiang Kelompok \\
\hline Panjang $(\mathrm{m})$ & 12 & 6 \\
Diameter $(\mathrm{mm})$ & 300 & 300 \\
Konfigurasi & - & $3 \times 2$ \\
f'c (MPa) & 30 & 25742960 \\
Modulus Young (kN/m2) & 25742960 & 50 \\
Selimut Beton (mm) & 50 & $2,5 \times 1,75$ \\
Pile Cap $(\mathrm{m})$ & $2,5 \times 1,75$ &
\end{tabular}

Untuk pengujian tiang tunggal sendiri pada program numerik, dilakukan untuk pencocokan data defleksi yang terjadi pada tiang tunggal. Pada Tabel 2. sampai Tabel 7. didapat parameter tanah untuk program numerik tiang tunggal dan kelompok sebagai berikut: 
Tabel 2. Data parameter program numerik tiang tunggal (tanah kohesif)

\begin{tabular}{|c|c|c|c|c|c|}
\hline $\begin{array}{c}\text { Layer } \\
(\text { Depth }, m)\end{array}$ & Soil Type & $\begin{array}{c}\text { Eff. Unit } \\
\text { Weight } \\
\left(\mathrm{kN} / \mathrm{m}^{3}\right) \text { : }\end{array}$ & $\begin{array}{c}\text { Und. Cohesion (c) } \\
\left(k N / m^{2}\right)\end{array}$ & $\begin{array}{c}p-y \text { modulus }(k N \\
\left./ m^{3}\right)\end{array}$ & $\begin{array}{c}\text { Strain Factor } \\
(\varepsilon)\end{array}$ \\
\hline $0-1$ & $\begin{array}{c}\text { Stiff Clay w/ Free } \\
\text { Water }\end{array}$ & 16,5 & 63 & 135000 & 0,007 \\
\hline $1-3$ & $\begin{array}{c}\text { Stiff Clay w/ Free } \\
\text { Water }\end{array}$ & 6,5 & 65 & 135000 & 0,007 \\
\hline $3-7,5$ & $\begin{array}{c}\text { Stiff Clay w/ Free } \\
\text { Water }\end{array}$ & 6,5 & 83 & 135000 & 0,007 \\
\hline $7,5-10,5$ & $\begin{array}{c}\text { Stiff Clay w/ Free } \\
\text { Water }\end{array}$ & 6,5 & 148 & 138000 & 0,006 \\
\hline $10,5-12$ & $\begin{array}{c}\text { Stiff Clay w/ Free } \\
\text { Water }\end{array}$ & 6,5 & 130 & 140000 & 0,005 \\
\hline
\end{tabular}

Tabel 3. Data parameter program numerik tiang kelompok (tanah kohesif)

\begin{tabular}{|c|c|c|c|c|c|}
\hline $\begin{array}{c}\text { Layer } \\
(\text { Depth, } m)\end{array}$ & Soil Type & $\begin{array}{c}\text { Eff. Unit } \\
\text { Weight }(k N \\
\left./ m^{3}\right)\end{array}$ & $\begin{array}{c}\text { Und. Cohesion (c) } \\
\left(k N / m^{2}\right)\end{array}$ & $\underset{\left(k N / m^{3}\right)}{p-y \bmod .(k)}$ & $\begin{array}{c}\text { Strain Factor } \\
(\varepsilon)\end{array}$ \\
\hline $0-1$ & $\begin{array}{c}\text { Stiff Clay w/ Free } \\
\text { Water }\end{array}$ & 16,5 & 63 & 135000 & 0,007 \\
\hline $1-3$ & $\begin{array}{c}\text { Stiff Clay w/ Free } \\
\text { Water }\end{array}$ & 6,5 & 65 & 135000 & 0,007 \\
\hline $3-7,5$ & $\begin{array}{c}\text { Stiff Clay w/ Free } \\
\text { Water }\end{array}$ & 6,5 & 83 & 135000 & 0,007 \\
\hline $7,5-10,5$ & $\begin{array}{c}\text { Stiff Clay w/ Free } \\
\text { Water }\end{array}$ & 6,5 & 148 & 138000 & 0,006 \\
\hline $10,5-12$ & $\begin{array}{c}\text { Stiff Clay w/ Free } \\
\text { Water }\end{array}$ & 6,5 & 130 & 140000 & 0,005 \\
\hline
\end{tabular}

Tabel 4. Data parameter program numerik tiang tunggal (tanah non-kohesif)

\begin{tabular}{|c|c|c|c|c|c|}
\hline $\begin{array}{c}\text { Layer } \\
(\text { Depth, } m)\end{array}$ & Soil Type & $\begin{array}{c}\text { Eff. Unit Weight } \\
\left(k N / m^{3}\right):\end{array}$ & $\begin{array}{c}\text { Und. } \\
\text { Cohesion (c) } \\
\left(k N / m^{2}\right)\end{array}$ & $\begin{array}{c}p-y \text { modulus } \\
\left./ m^{3}\right)\end{array}$ & $\begin{array}{c}\text { Strain Factor } \\
(\varepsilon)\end{array}$ \\
\hline $0-1$ & $\begin{array}{l}\text { Sands } \\
\text { (Reese) }\end{array}$ & 16,5 & 63 & 35000 & 0,007 \\
\hline $1-3$ & $\begin{array}{l}\text { Sands } \\
\text { (Reese) }\end{array}$ & 6,5 & 65 & 35000 & 0,007 \\
\hline $3-7,5$ & $\begin{array}{l}\text { Sands } \\
\text { (Reese) }\end{array}$ & 6,5 & 83 & 35000 & 0,007 \\
\hline $7,5-10,5$ & $\begin{array}{l}\text { Sands } \\
\text { (Reese) }\end{array}$ & 6,5 & 148 & 40000 & 0,006 \\
\hline $10,5-12$ & $\begin{array}{c}\text { Sands } \\
\text { (Reese) }\end{array}$ & 6,5 & 130 & 42000 & 0,005 \\
\hline
\end{tabular}


Tabel 5. Data parameter program numerik tiang tunggal (tanah non-kohesif)

\begin{tabular}{|c|c|c|c|c|c|}
\hline $\begin{array}{c}\text { Layer } \\
(\text { Depth }, m)\end{array}$ & Soil Type & $\begin{array}{c}\text { Eff. Unit Weight } \\
\left(\mathrm{kN} / \mathrm{m}^{3}\right):\end{array}$ & $\begin{array}{c}\text { Und. Cohesion (c) } \\
\left(\mathrm{kN} / \mathrm{m}^{2}\right)\end{array}$ & $\begin{array}{c}p-y \text { modulus } \\
\left(k m^{3}\right)\end{array}$ & $\begin{array}{c}\text { Strain } \\
\text { Factor }(\varepsilon)\end{array}$ \\
\hline $0-1$ & $\begin{array}{l}\text { Sands } \\
\text { (Reese) }\end{array}$ & 16,5 & 63 & 35000 & 0,007 \\
\hline $1-3$ & $\begin{array}{l}\text { Sands } \\
\text { (Reese) }\end{array}$ & 6,5 & 65 & 35000 & 0,007 \\
\hline $3-7,5$ & $\begin{array}{l}\text { Sands } \\
\text { (Reese) }\end{array}$ & 6,5 & 83 & 35000 & 0,007 \\
\hline $7,5-10,5$ & $\begin{array}{l}\text { Sands } \\
\text { (Reese) }\end{array}$ & 6,5 & 148 & 40000 & 0,006 \\
\hline $10,5-12$ & $\begin{array}{l}\text { Sands } \\
\text { (Reese) }\end{array}$ & 6,5 & 130 & 42000 & 0,005 \\
\hline
\end{tabular}

Tabel 6. Tabel parameter finite element - mohr coulomb model (tanah kohesif)

\begin{tabular}{cccc}
\hline \multirow{2}{*}{ Parameter } & \multicolumn{3}{c}{ Mohr-Coulomb $(M C)$} \\
\cline { 2 - 4 } & Layer $1,(0-2) \mathrm{m}$ & Layer $2,(2-5,5) \mathrm{m}$ & Layer 3, $(5,5-8,5) \mathrm{m}$ \\
\hline Drain. Type & Undrained $(B)$ & Undrained $(B)$ & Undrained $(B)$ \\
$\gamma$ sat $\left(\mathrm{kN} / \mathrm{m}^{3}\right)$ & 15,51 & 15,66 & 17,37 \\
$\gamma$ unsat $\left(\mathrm{kN} / \mathrm{m}^{3}\right)$ & 12,9 & 15,56 & 16,70 \\
$\mathrm{E}\left(\mathrm{kN} / \mathrm{m}^{2}\right)$ & 2500 & 2500 & 4000 \\
$v$ & 0,35 & 0,35 & 0,35 \\
$\mathrm{Su}\left(\mathrm{kN} / \mathrm{m}^{2}\right)$ & 53 & 55 & 84 \\
Rinter & 0,1 & 0,7 & 0,7 \\
\hline
\end{tabular}

Tabel 7. Tabel parameter finite element - hardening soil model (tanah kohesif)

\begin{tabular}{cccc}
\hline \multirow{2}{*}{ Parameter } & \multicolumn{3}{c}{ Hardening Soil $(H S)$} \\
\cline { 2 - 4 } & Layer $1,(0-2) \mathrm{m}$ & Layer $2,(2-5,5) \mathrm{m}$ & Layer 3, $(5,5-8,5) \mathrm{m}$ \\
\hline Drain. Type & Undrained $(B)$ & Undrained $(B)$ & Undrained $(B)$ \\
$\gamma$ sat $\left(\mathrm{kN} / \mathrm{m}^{3}\right)$ & 15,51 & 15,66 & 17,37 \\
$\gamma$ unsat $\left(\mathrm{kN} / \mathrm{m}^{3}\right)$ & 12,9 & 15,56 & 16,70 \\
einit $\left(\mathrm{kN} / \mathrm{m}^{2}\right)$ & 1,9865 & 1,8469 & 1,2348 \\
$\mathrm{cc}$ & 0,9500 & 0,9500 & 0,6580 \\
$\mathrm{cs}$ & 0,2000 & 0,2000 & 0,1510 \\
Rinter & 0,1 & 0,7 & 0,7 \\
OCR & 5,1054 & 5,1399 & 4,8486 \\
\hline
\end{tabular}

Pada Finite Element, kelompok tiang harus diurutkan sesuai dengan staged constuctionnya. Dimulai dari install bored-pile, kemudian pengecoran pile cap, dan akhirnya pembebanan secara siklik dengan arah vertikal dan juga horizontal dari sumbu kartesius. Pada Gambar 1. diperlihatkan pemodelan dari kelompok pile konfigurasi $3 \times 2$ terhadap tanah kohesif dan non-kohesif: 


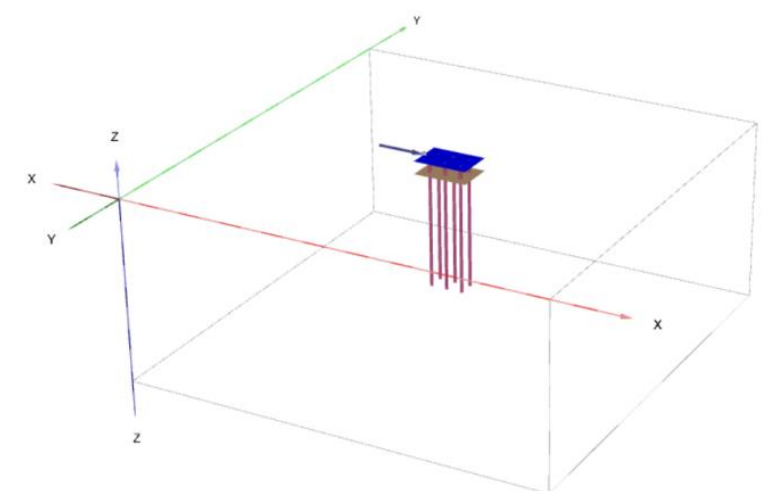

Gambar 1. Pemodelan kelompok pile pada finite element

\section{HASIL DAN PEMBAHASAN}

\section{Tiang Tunggal}

Berdasarkan percobaan statik yang dilakukan pada lapangan dan juga menggunakan analisa program numerik tiang tunggal, ditemukan kemiripan dari segi defleksi yang dihasilkan terhadap pembebanan yang dihasilkan. Pembebanan yang dipakai pada Load Cell (Single Pile) sendiri dilakukan dengan cara statik dikarenakan kapasitas lateral yang terus naik seiring pertambahan defleksi, sehingga pemodelan pembebanan dilakukan secara statik juga. Pada Tabel 8. terlihat perbandingan antara hasil lapangan (load cell) dan juga program numerik untuk tiang tunggal:

Tabel 8. Perbandingan load cell vs program numerik tiang tunggal (single pile)

\begin{tabular}{ccc}
\hline Beban (Ton) & Load Cell (mm) & $\begin{array}{c}\text { Disp. Prog. } \\
\text { Numerik (mm) }\end{array}$ \\
\hline 0 & 0 & 0 \\
1 & 0,7 & 0,9127 \\
2 & 4,47 & 4,6241 \\
3 & 13,6 & 17,5982 \\
3,288 & 25 & 24,4288 \\
\hline
\end{tabular}

Berikut juga merupakan rujukan gambar yang menunjukan hasil plotting dari Tabel 8. yaitu perbandingan load vs displacement pada beban statik yang dijabarkan pada Gambar 2. sebagai berikut: 


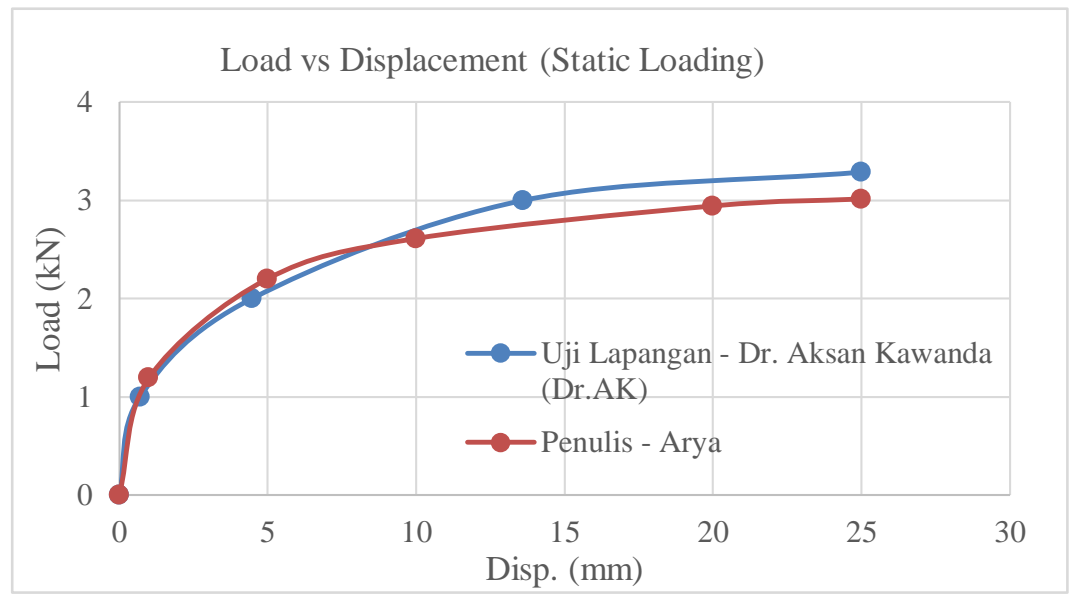

Gambar 2. Kurva perbandingan load cell vs program numerik (single pile)

Pada data yang tertera diatas, dan juga kurva yang telah diplot, menyatakan bahwa pada kondisi tersebut, parameter yang dipakai sudah dikatakan cukup akurat baik secara material maupun parameter tanah yang dipakai. Berikut merupakan kapasitas lateral yang sudah dikonversi menjadi beban static unloading-reloading pada tiang tunggal tersebut (Free-Headed dan Fixed-Headed Pile):

Berikut merupakan gambar yang menunjukan hasil perbandingan load vs displacement pada beban siklik yang dijabarkan pada Gambar 3. sebagai berikut:

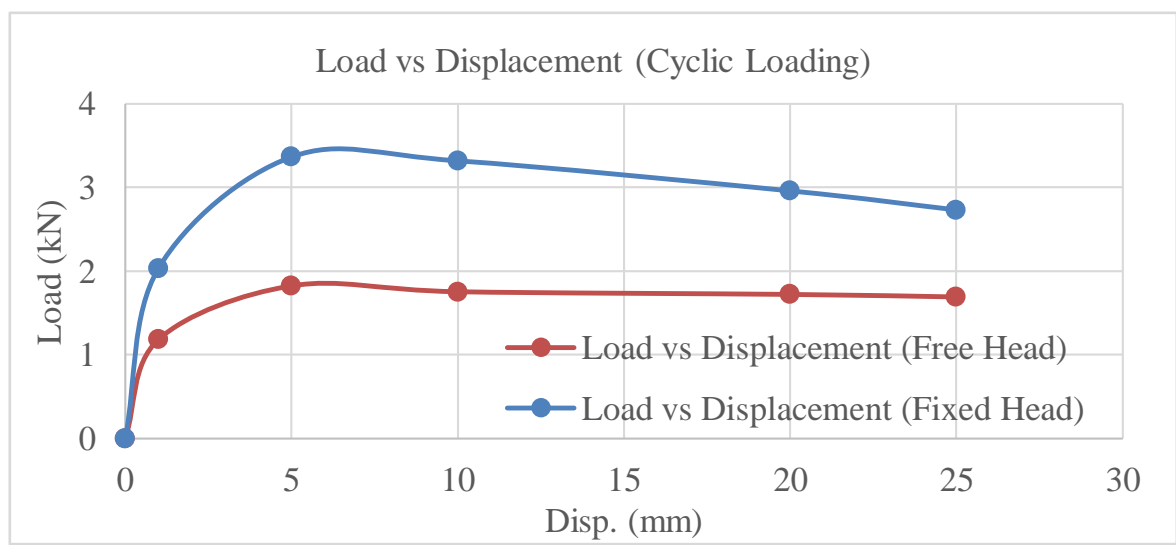

Gambar 3. Load vs displacement (free-fixed head / single pile)

Pada grafik diatas, terlihat bahwa kapasitas lateral maksimum terhadap beban siklik untuk kepala tiang bebas yaitu $\mathbf{1 8 , 2 1 9 3} \mathbf{~ k N}$, sedangkan untuk kepala tiang terjepit yaitu 33,615 kN. Perbedaam kapasitas lateral tersebut untuk kepala tiang bebas dan terjepit terlampau cukup jauh dengan presentase sebesar $\mathbf{5 4 , 2 \%}$.

Selain untuk menguji kapasitas lateral, dicari juga untuk defleksi maksimum yang akan terjadi apabila diberikan pembebanan. Untuk menguji defleksi maksimum pada tiang, digunakan Metode Broms untuk mengidentifikasinya, dan juga SNI 8460:2017 untuk mengecek defleksi maksimum pada gempa rencana dan gempa maksimum. Rumus yang dipakai untuk Metode Broms untuk mencari defleksi maksimum untuk tiang panjang, tanah kohesif (Free-Head) adalah:

$$
y o=\frac{4 \cdot H u \cdot \beta(e \beta+1)}{k h \cdot b}
$$

dengan yo $=$ defleksi maksimum, $\mathrm{Hu}=$ gaya lateral maksimum, $\beta=$ koefisien Broms, $\mathrm{kh}=$ modulus subgrade. 
Rumus yang dipakai untuk Metode Broms untuk mencari defleksi maksimum untuk tiang panjang, tanah nonkohesif (Free-Head) adalah:

$$
y o=\frac{0.93 H u}{(n h)^{0.6} \cdot(E p . I p)^{0.4}}
$$

dengan yo = defleksi maksimum, $\mathrm{Hu}=$ gaya lateral maksimum, $n h=$ koefisien Briaud $\&$ Smith, Ep = modulus elastisitas pile, $\mathrm{Ip}=$ inersia pile.

Pada Tabel 9. dapat dilihat defleksi maksimum pile terhadap beban lateral pada beban rencana dan kuat yang dapat dirangkum beserta dengan pemenuhan syarat dari SNI 8460:2017, sebagai berikut:

Tabel 9. Defleksi maksimum pile terhadap beban lateral rencana dan kuat

\begin{tabular}{ccccc}
\hline Tanah: & $\begin{array}{c}\text { Defleksi Max } \\
(\mathrm{mm}):\end{array}$ & $\begin{array}{c}\text { Lateral } \\
\text { Rencana }(\mathrm{mm})\end{array}$ & $\begin{array}{c}\text { Lateral Kuat } \\
(\mathrm{mm})\end{array}$ & (OK/TIDAK) \\
\hline $\begin{array}{c}\text { Kohesif }(\text { Free }- \\
\text { Head })\end{array}$ & 8,1774 & 12 & 25 & OK \\
$\begin{array}{c}\text { Non-Kohesif } \\
(\text { Free-Head })\end{array}$ & 6,2026 & 12 & 25 & OK \\
\hline
\end{tabular}

Defleksi yang terjadi pada pile di tanah kohesif dan non-kohesif sendiri terjadi akibat pembebanan pada Hu ijin pada masing-masing kepala tiang. Untuk pembebanan lateral pada pondasi digunakan Safety Factor $=3(\mathbf{S F}=\mathbf{3})$. Pembebanan ijin pada tanah kohesif yaitu sebesar $\mathbf{1 7 , 7 8 0 6} \mathbf{k N}$, sedangkan untuk pembebana ijin pada tanah nonkohesif sebesar 33,4087 kN.

\section{Tiang Kelompok}

Untuk tiang kelompok sendiri, penulis menggunakan Finite Element sebagai acuan perhitungan yang dipakai. Pencocokan data sendiri dimulai dengan melihat data tiang tunggal akibat beban lateral dengan menggunakan Finite Element. Untuk tiang tunggal sendiri, dibagi menjadi 4 kategori, yaitu Kohesif - Free Head, Kohesif - Fixed Head, Non-Kohesif - Free Head, Non-Kohesif - Fixed Head. Untuk jenis pemodelan pembebanan, penulis menggunakan model Hardening Soil sebagai acuan untuk Finite Element. Alasannya, karena kurva yang dihasilkan lebih hiperbolic sehingga dapat cukup terlihat kemiripan antara kurva program numerik dengan program Finite Element. Berikut merupakan hasil dari pengujian program numerik tiang tunggal dengan program Finite Element untuk Top Shear vs Displacement pada tanah kohesif dan non-kohesif dengan kondisi kepala tiang bebas sebagai contoh pada Gambar 4. dan Gambar 5. sebagai berikut:

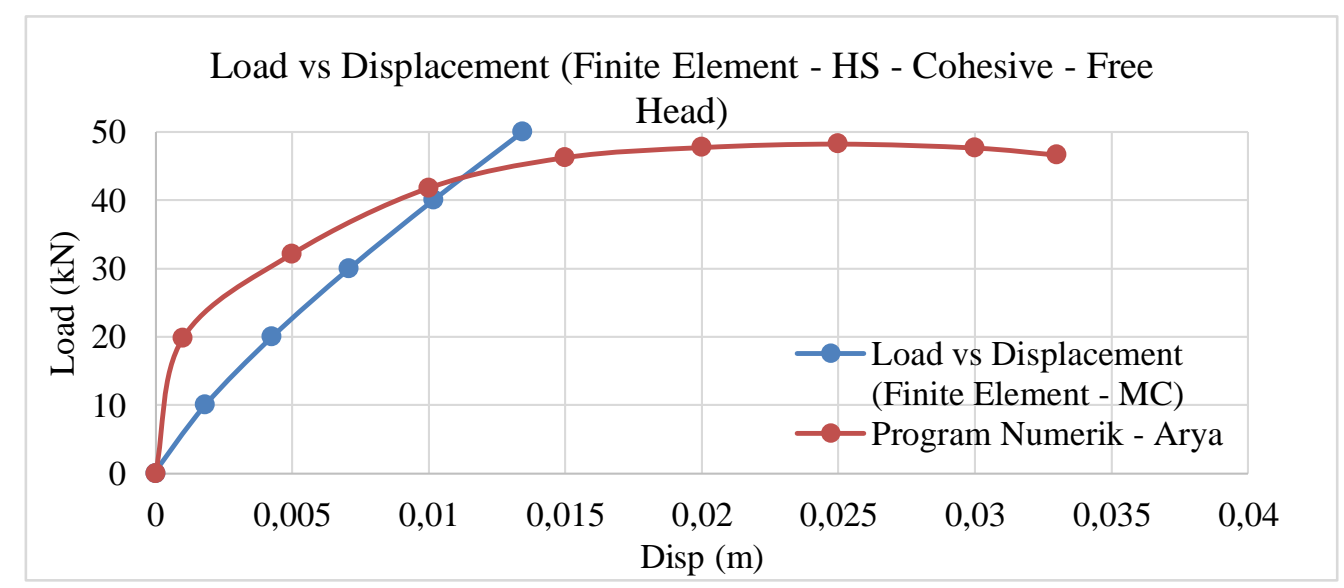

Gambar 4. Load vs displacement (finite element group pile - free head - tanah kohesif) 


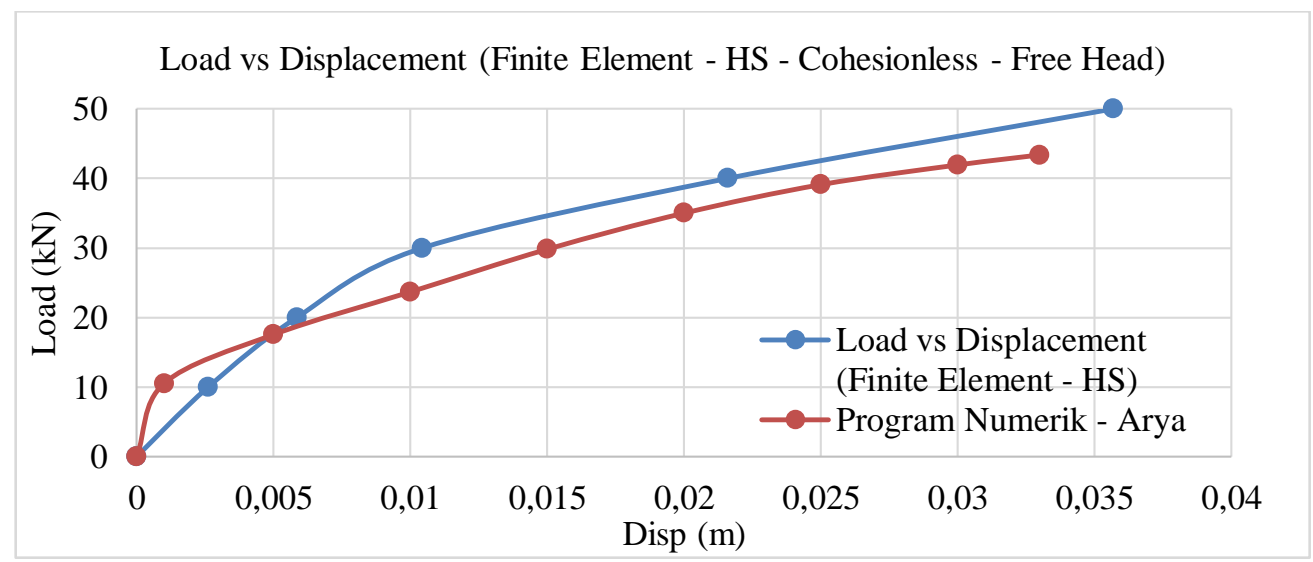

Gambar 5. Load vs displacement (finite element group pile - free head - tanah non-kohesif)

Ketika data sudah matching, maka artinya parameter yang digunakan pada Finite Element dan juga program numerik juga sudah baik. Sehingga dapat dilanjutkan untuk mencari nilai efisiensi yang dibutuhkan pada tiang kelompok tersebut. Setelah itu, untuk menentukan efisiensi yang dipakai, penulis harus menentukan kurva interpolasi top shear vs displacement sebagai kurva efisiensi, untuk menjadi sebuah perbandingan dengan kapasitas lateral pada Finite Element.

Kurva interpolasi didapatkan dengan cara mengalikan hasil top shear vs displacement pada program numerik dengan nilai $\mathrm{P}$ multiplier sebesar $0,1-1$ ( $\mathrm{P}=1$ adalah kondisi asli tiang tunggal). Setelah kurva interpolasi didapatkan, maka dapat dibuat pemodelan finite element dengan acuan Hardening Soil sebagai tolok ukut pemodelan tanah. Gambar 6. merupakan hasil contoh pemodelan grup pile pada Finite Element:

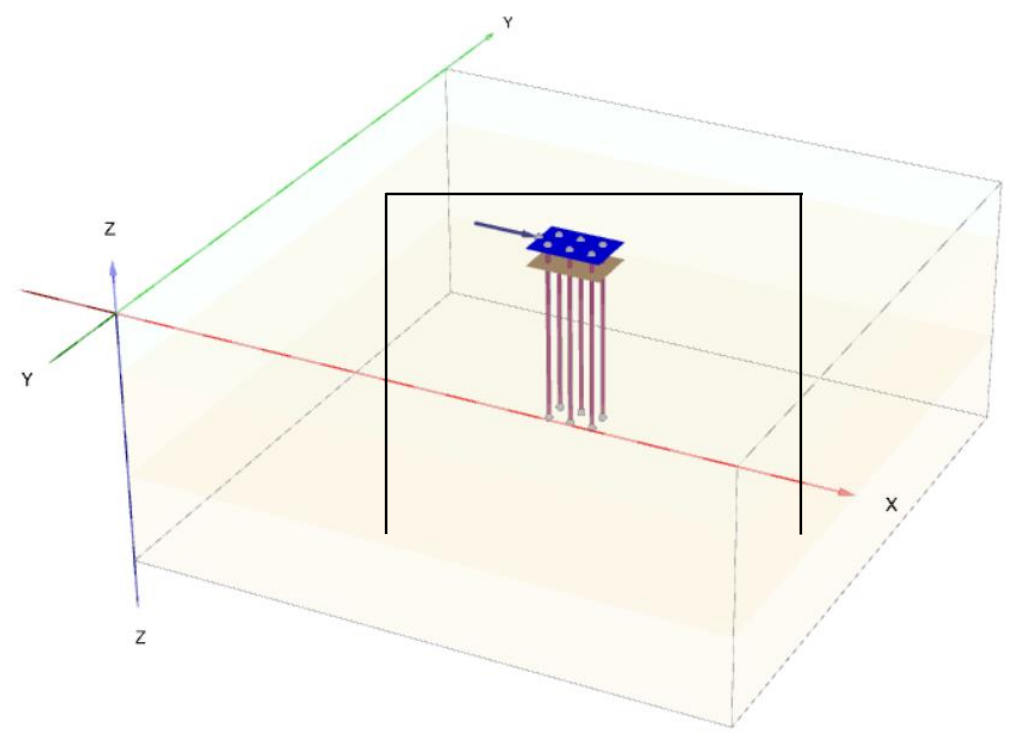

Gambar 6. Pemodelan finite element pada group pile

Setelah staged construction dilakukan, maka selanjutnya adalah melihat hasil perbandingan antara kurva interpolasi dengan hasil yang ada pada Finite Element, berikut merupakan contoh hasil efisiensi grup pile pada Finite Element pada kondisi kepala tiang bebas dengan tanah kohesif dan In-Line Loading, beserta tabulasi akhir mengenai efisiensi keseluruhan untuk semua kondisi kepala tiang maupun kondisi tanah masing-masing yang terangkum pada Tabel 10. dan Tabel 11: 
Tabel 10. Tabulasi efisiensi pile terhadap tanah kohesif

\begin{tabular}{ccccc}
\hline \multirow{2}{*}{ Eff. Pile } & \multicolumn{4}{c}{ TANAH KOHESIF } \\
\cline { 2 - 5 } & $F R . H E A D I L(H S)$ & $F X . H E A D I L(H S)$ & $F R . H E A D S B S(H S)$ & $F X . H E A D S B S(I L)$ \\
\hline 1 & 0,65 & 0,36 & 0,53 & 0,36 \\
2 & 0,55 & 0,31 & 0,57 & 0,42 \\
3 & 0,22 & 0,23 & 0,22 & 0,17 \\
4 & 0,32 & 0,31 & 0,22 & 0,17 \\
5 & 0,60 & 0,33 & 0,65 & 0,42 \\
6 & 0,47 & 0,26 & 0,68 & 0,45 \\
\hline
\end{tabular}

Untuk tanah non-kohesif juga sama seperti tanah non-kohesif. Dengan pembebanan yang sama, namun berbeda kondisi tanah. Tanah yang dipakai adalah tanah Sands (Reese) dengan klasifikasi tanah Medium Dense, juga dibagi menjadi 2 bagian lapisan tanah yaitu AWT (Above Water Table) dan juga BWT (Below Water Table).

Tabel 11. Tabulasi efisiensi pile terhadap tanah non-kohesif

\begin{tabular}{ccccc}
\hline \multirow{2}{*}{ Eff. Pile } & \multicolumn{4}{c}{ TANAH NON-KOHESIF } \\
\cline { 2 - 5 } & $F R . H E A D I L(H S)$ & $F X . H E A D I L(H S)$ & $F R . H E A D S B S(H S)$ & $F X$. HEAD SBS (IL) \\
\hline 1 & 0,70 & 0,38 & 0,98 & 0,65 \\
2 & 0,69 & 0,40 & 0,60 & 0,46 \\
3 & 0,55 & 0,45 & 0,84 & 0,58 \\
4 & 0,54 & 0,53 & 0,48 & 0,29 \\
5 & 0,96 & 0,63 & 0,98 & 0,64 \\
6 & 0,98 & 0,62 & 0,67 & 0,48 \\
\hline
\end{tabular}

Berikut merupakan hasil tabulasi dari contoh tanah kohesif dengan kepala tiang bebas dan tiang terjepit pada pemodelan tanah Hardening Soil yang akan dibandingkan dengan program numerik dengan pembebanan In-Line Loading. Akan digambarkan pada Gambar 7. sampai Gambar 10. sebagai berikut: 


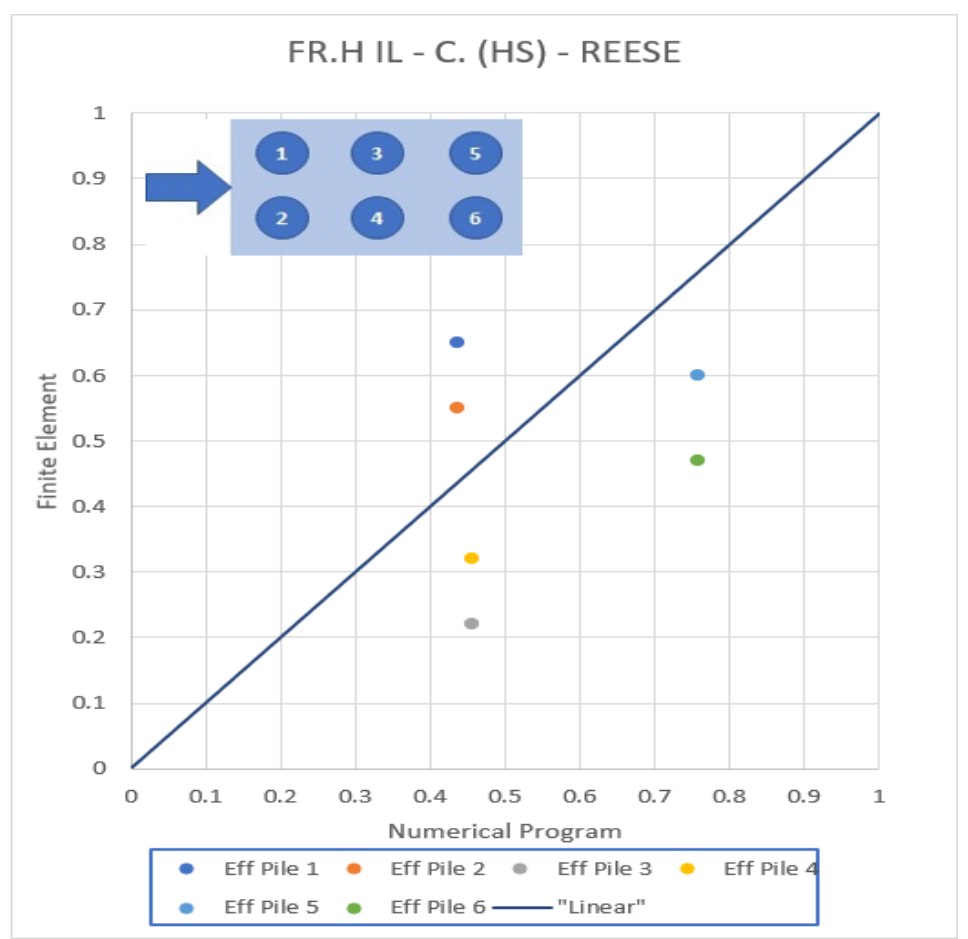

Gambar 7. Perbandingan efisiensi program numerik dan finite element (Fr.H - IL - C - HS) - Reese, et al (2011)

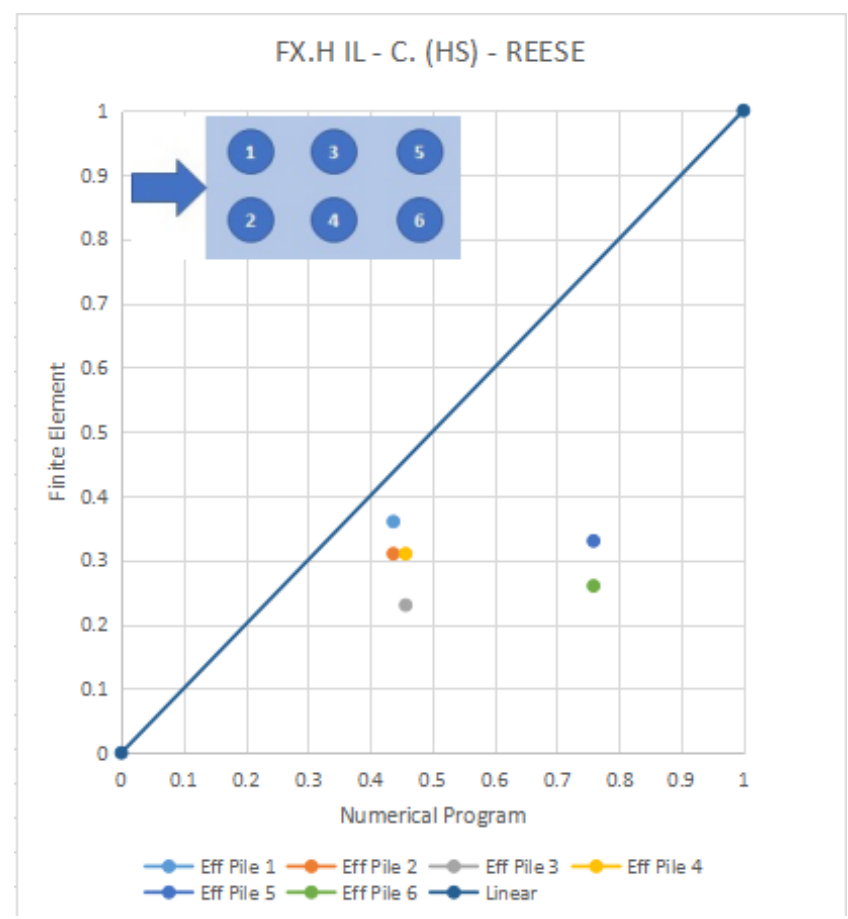

Gambar 8. Perbandingan efisiensi program numerik dan finite element (Fx.H - IL - C - HS) - Reese, et al (2011)

Berikut juga merupakan hasil tabulasi dari contoh tanah non-kohesif dengan kepala tiang bebas dan tiang terjepit pada pemodelan tanah Hardening Soil yang akan dibandingkan dengan program numerik dengan pembebanan InLine Loading. Sebagai berikut: 


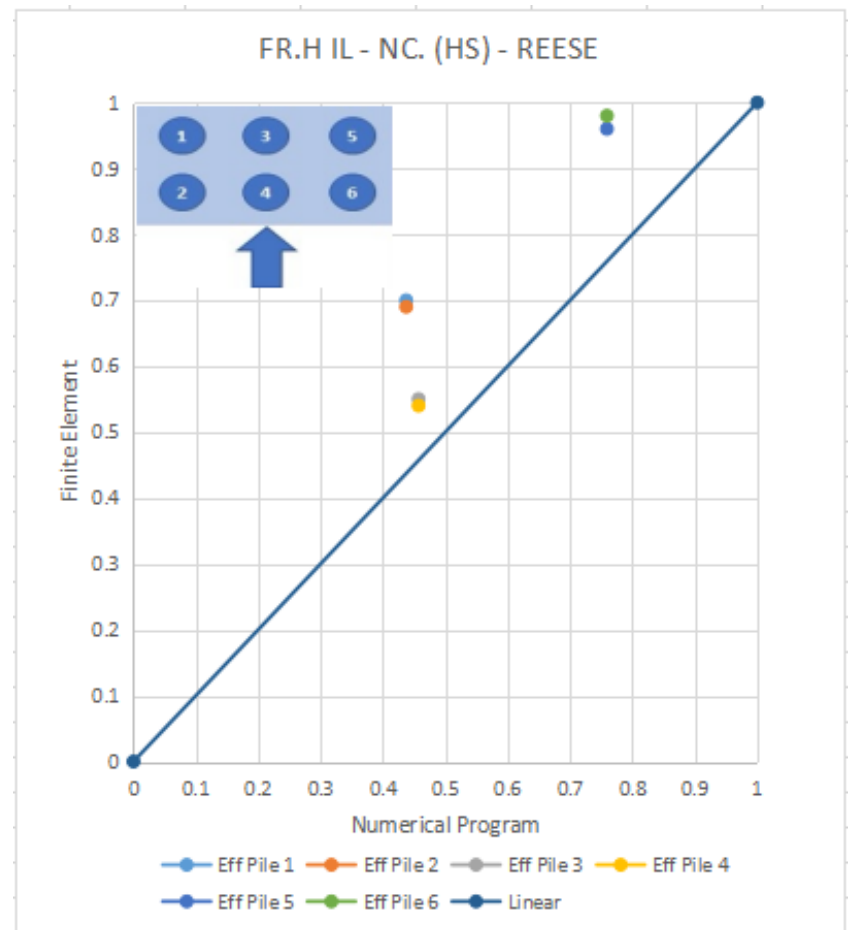

Gambar 9. Perbandingan efisiensi program numerik dan finite element (Fr.H - IL - NC - HS) - Reese, et al (2011)

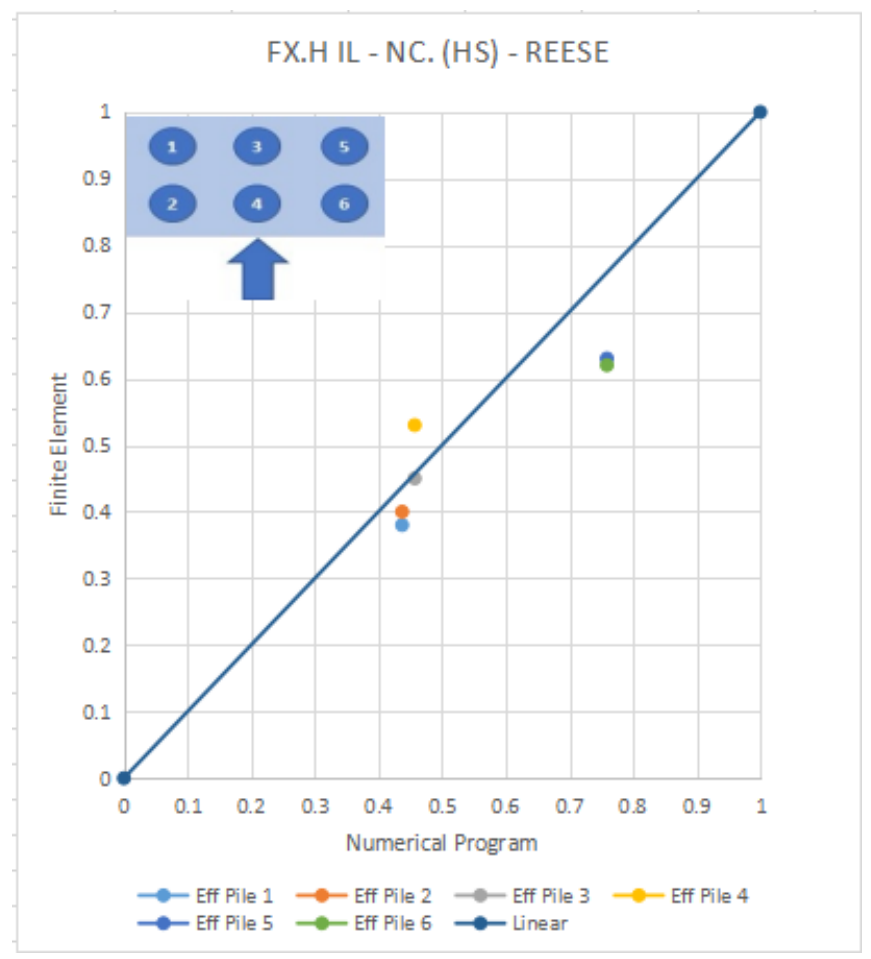

Gambar 10. Perbandingan efisiensi program numerik dan finite element (Fx.H - IL - NC - HS) - Reese, et al (2011) 


\section{KESIMPULAN DAN SARAN}

\section{Kesimpulan}

- Tanah kohesif dan non-kohesif mempunyai daya dukung yang berbeda. Terlihat pada P-Y Curves yang didapat berdasarkan hasil percobaan pada buku "Single Pile and Group Piles under Lateral Loading $2^{\text {nd }}$ Edition". Terlihat pada masing-masing hasil single pile dan group pile pada tanah kohesif, terlihat apabila resisten tanah mencapai maksimum, maka tanah akan kehilangan resistensinya, sedangkan tanah nonkohesif cenderung konstan apabila mencapai resistensi maksimum. Contoh: Single Pile - Cyclic-Cohesive Soils - Free Head, pada defleksi $10 \mathrm{~mm}$ mempunyai kapasitas shear sebesar 17,516 kN sedangkan pada defleksi 20 mm, kapasitas shear pada pile menurun sebesar 17,2003 kN. Sedangkan, untuk Single Pile Cyclic - Cohesionless Soils - Free Head, pada defleksi $10 \mathrm{~mm}$ mempunyai kapasitas shear sebesar $12,9387 \mathrm{kN}$, sedangkan untuk defleksi $20 \mathrm{~mm}$ kapasitas shear pada pile naik sebesar 15,5213 kN.

- Dengan spesifikasi pile yang sudah dibuat, pile tersebut perlu dicek terhadap defleksi menggunakan metode Broms. Perhitungan menunjukan defleksi untuk Free Head - Cohesive sebesar 8,1774 mm dan untuk Fixed Head - Cohesive sebesar 3,7288 mm. Sedangkan untuk defleksi pada Free Head - Cohesionless sebesar 4,1896 mm dan Fixed Head - Cohesionless sebesar 1,187 mm. Hasil ini telah dicek dengan ketentuan SNI 8460:2017 pasal 9.7.3.1, dan hasilnya memenuhi syarat gempa rencana dan gempa kuat.

- Efisiensi yang dihasilkan oleh aplikasi numerik dan juga metode Finite Element, menghasilkan efisiensi yang berbeda-beda. Efisiensi yang dihasilkan program numerik sendiri, lebih seragam bergantung pada posisi pile tersebut (Leading, Middle, Trailing). Contoh: Pada kondisi Free-Head - In-Line Loading, untuk aplikasi numerik pada tanah kohesif dan non-kohesif memiliki efisiensi pada pile 1 \& 2 yaitu 0,4372 , Pile $3 \& 4$ yaitu 0,4570 dan Pile $5 \& 6$ yaitu 0,7590. Sedangkan untuk aplikasi Finite Element sendiri pada tanah kohesif memiliki efisiensi untuk pile $1,2,3,4,5,6$ sebesar 0,$52 ; 0,45 ; 0,20 ; 0,28 ; 0,58 ; 0,46$. Untuk tanah non-kohesif sendiri memiliki efisiensi untuk pile 1,2,3,4,5,6 sebesar 0,$81 ; 0,69 ; 0,29 ; 0,44 ; 0,87$; 0,69. Pada data diatas, efisiensi pada Finite Element cenderung lebih bervariasi dibandingkan dengan program numerik.

\section{Saran}

- Untuk kedepannya, bagi yang ingin melanjutkan eksperimen ini, disarankan untuk dapat melakukan pengujian tes secara langsung. Dimulai dari proses pembuatan pile, dan juga pembebanan siklik secara langsung agar dapat lebih mengerti cara mendapatkan parameter dan langsung melihat kondisi tanah di lapangan serta step pembebanannya seperti apa.

- Untuk kedepannya, boleh dicoba untuk jenis pemodelan tanah yang lain selain dari akibat Mohr-Coulomb dan Hardening Soil pada aplikasi Finite Element apabila memungkinkan.

\section{DAFTAR PUSTAKA}

Das, Braja M. Fundamentals of Geotechnical Engineering "Third Edition". Madrid, Spain: Chris Carson, 1984.

Desai, Chandrakant S and Tribikram Kundu. Introductory Finite Element Method. Washington D.C: CRC Press LLC, 2001.

Hardiyatmo. Teknik Pondasi 1. Jakarta: PT. Gramedia Pustaka Umum, 1996.

Kawanda, Aksan. Penyelidikan Tanah - Inclinometer - Load Cell (Tiang Tunggal - Tiang Kelompok). Legok, Tanggerang: Rekayasa Geoteknik Indonesia, 2015.

Reese, Lymon C and William F. Van Impe. Single Pile and Pile Groups Under Lateral Loading 2nd Edition . London, UK: Taylor \& Francis Group, 2011. 